\title{
Parental Perception About Metered-Dose Inhalers and Nebulizers Differences Among Saudi Arabia
}

\author{
Abdullah A. Alzayed ${ }^{1}$, Amani S. Alotaibi ${ }^{1}$, Rahaf F. Alfadhli ${ }^{1}$, Renad A. Alageel $^{1}$, Wejdan S. Al-Saqat ${ }^{1}$, \\ Hussain A. Alghadeer ${ }^{2}$ \\ 1. Pediatric, College of Medicine, Imam Mohammad Ibn Saud Islamic University, Riyadh, SAU 2. Pediatric, College of \\ Medicine, King Faisal University, Al-Ahsa, SAU
}

Corresponding author: Hussain A. Alghadeer, hussain.ghg14@gmail.com

\section{Abstract \\ Background}

Asthma is a common public health issue in the pediatric population. The prevalence of asthma in children in Saudi Arabia is increasing. All asthmatic children with continuous symptoms should use controller medications. These medications if used correctly by the patients will diminish the symptoms and avoid exacerbations that lead to hospitalization. Perception of parents toward a particular device can affect the adherence rate.

\section{Aim}

Assessing the parental perception about metered-dose inhalers (MDIs) and nebulizers differences among the Saudi population.

\section{Methods}

A cross-sectional study was conducted to assess Parental perception about MDIs and nebulizers among Saudi parents with an asthmatic child. The data were collected from the parents and caregivers by using an online questionnaire and informed consent was obtained. The questionnaire was focused on demographic characteristics, knowledge, perception and practice of treating the asthmatic child. Data were analyzed through the Statistical Package for the Social Sciences (SPSS) version 25 (IBM Corp., Armonk, NY) and the results were considered statistically significant if $\mathrm{P}<0.05$.

\section{Results}

A total of 1,021 participants included in this study. This study found asthma is predominant in males (64.4\%) and the most affected age is between 8 and 14 years (56.3\%). More than half of the parents (58.7\%) had a bachelor's degree and above. MDI is the most method used for controlling asthma (32.7\%) and the majority of them (70.2\%) thought there is a therapeutic difference between MDI and nebulizer. Providing instructions and information on usage MDI was received from $65.2 \%$. Significant relationships were found

Review began 02/13/2021 Review ended 02/25/2021 Published 02/25/2021

\section{() Copyright 2021}

Alzayed et al. This is an open access article distributed under the terms of the Creative Commons Attribution License CC-BY 4.0., which permits unrestricted use, distribution, and reproduction in any medium, provided the original author and source are credited.

\section{Conclusion}

This study found that asthma is more prevalent in males, where MDI is more common. Majority of the parents had thought that there is a difference in the therapeutic effects between MDI and nebulizer. They believed that nebulizer is more effective, less side effect and cheaper while MDI is easier to use.

Categories: Pediatrics, Allergy/Immunology, Pulmonology

Keywords: asthma, pediatric, mdi, nebulizer, perception

\section{Introduction}

Asthma is a chronic disorder and a common public health issue, especially among the pediatric population. Bronchial asthma is defined as a chronic medical condition that causes inflammation of the airways. The chronic inflammation will cause an increase in the hyper-responsiveness of the airways that results in breathlessness, chest tightness, recurrent episodes of wheezing and coughing especially in the early morning or at night. These episodes are generally connected with diffuse airflow obstruction that is usually reversible either developing without apparent external influence or with treatment [1]. The terms "chest allergy" and "dyspnea” are usually used instead of asthma in developing countries to avoid the social stigma related to the chronic nature of the disease [2].

The prevalence of asthma in children in Saudi Arabia is increasing rapidly [2] and fluctuates among various areas throughout the country. The highest prevalence among all reigns was in Alhofuf (33.7\%) and the 
lowest prevalence was in Abha (9\%) [3]. In Saudi Arabia, asthma has become one of the most common chronic disease, mostly related to the changes in lifestyle and modernization of Saudi society, the changes in eating habits, and excessive exposure to environmental factors such as dust, tobacco and sandstorms [2].

The National Heart, Lung and Blood Institute (NHLBI) of the National Institutes of Health has built up guidelines for the diagnosis and management of asthma (NHLBI, 1997) [4]. These guidelines state four things that should be done to control asthma: (a) regular assessment and monitoring of symptoms, (b) giving the appropriate medication, (c) taking control of environmental triggers and patient education, and (d) building relationship with families (NHLBI,1997) [4].

National guidelines state that all asthmatic children with continuous symptoms should use controller medications to achieve the greatest asthma control. These medications, if used correctly by the patients it will diminish the symptoms and avoid exacerbations that lead to hospitalization [5].

One study found that parents of asthmatic patients think the inhaler is easier to use when compared with the nebulizer, in the parent's opinion the nebulizer works better and a good system of delivery. The level of parent's education did not affect $(\mathrm{P}=0.584)$ the selection of the medication whether metered-dose inhalers (MDIs) or nebulizers. The reason for parental preference for nebulizer compared to MDIs were varied [6]. Moreover, it was found that misperceptions lead to ineffective behaviors and practices in the management of asthmatic child [2]. Also, cross-sectional study published in Aminu Kano Teaching Hospital, Kano in 2017 suggest by Structured questionnaires that parental education has a great impact in accepting the better kind of treating asthmatic child [7].

It is crucial to evaluate parental perception of MDIs and nebulizers because it has an impact on the adherence of the medication and it may be modified by building a better doctor-patient relationship and discussion. Therefore, our main objective of this study is to assess the parental perception about MDI and Nebulizers differences among the Saudi population.

\section{Materials And Methods \\ Study design and population}

Analytical cross-sectional survey was conducted during November to December 2020 to assess parental perception about MDIs and nebulizers The population of the study consisted of parents with asthmatic child in Saudi Arabia.

\section{Sample size and sampling strategy}

A sample size equal to 1,594 participants completed the survey.

\section{Data collection}

The data were collected through an electronic questionnaire distributed among parents with asthmatic child. Informed consent obtained from all the participants for completion of the survey considering the maximum privacy, safety and confidentiality. Inclusion criteria that all children diagnosed with asthma and using either MDI or nebulizer. Excluding parents for healthy children not using any kind of inhalers. The questionnaire included demographic characteristics, knowledge, perception and practice was assessed by descriptive statistics.

\section{Data analysis}

Data were analyzed through the Statistical Package for the Social Sciences (SPSS), version 25 (IBM Corp., Armonk, NY). Mean and standard deviation used to calculate the continuous data, frequencies, and percentages for categorical data and chi-square were considered statistically significant at $\mathrm{P}$ values $<0.05$.

\section{Data management}

Data is stored in a database on a safe computer within an encrypted file, and it is only shown to the research team. Privacy and confidentiality are maintained under all circumstances.

\section{Ethical consideration and issues}

For study protocol/study design/methodology: the study was approved by the medical ethics committee of Al-Imam Muhammad Ibn Saud Islamic University, Institution Review Board (IRB), RegistrationL HAPO-01R-011 (ethical approval code: 98-2020).

\section{Results}

In this study, 1,594 subjects completed the survey. Excluded participants were $35.9 \%$ that didn't meet the criteria of this study. The study was completed by over 1021 participants. 


\section{Cureus}

Table 1 shows the demographical data of the participants. More than half of parents reported having asthmatic children between the age of 8 and 14 years (56.3\%) while $43.7 \%$ were younger than seven years. The prevalence of asthma was predominant in males $64.4 \%$ in ratio 2:1 (M:F). Majority of the participants $68.9 \%$ were between the age of 30 years or older while $31.1 \%$ were between 19 and 29 years. Educational level of the most caregivers $58.7 \%$ were bachelor degree or above education and $23.9 \%$ at level of high school. Lower percentage of them $17.4 \%$ were at the level of primary or intermediate education.

\begin{tabular}{|c|c|c|}
\hline & & N (\%) \\
\hline \multirow{2}{*}{ Age of child } & $<7$ & $446(43.7)$ \\
\hline & $8-14$ & 575 (56.3) \\
\hline \multirow{2}{*}{ Child's gender } & Male & $658(64.4)$ \\
\hline & Female & $363(35.6)$ \\
\hline \multirow{2}{*}{ Age of caregiver } & $19-29$ years & $318(31.1)$ \\
\hline & 30 years and above & 703 (68.9) \\
\hline \multirow{3}{*}{ Level of education } & Primary/intermediate school level & 178 (17.4) \\
\hline & High school & $244(23.9)$ \\
\hline & Bachelor degree and above & 599 (58.7) \\
\hline
\end{tabular}

TABLE 1: Demographic data of participants.

Figure 1 shows the treatment options for controlling asthma. About $32.7 \%$ of asthmatic children use MDI with spacers as treatment for their condition while $20.5 \%$ of them using of nebulizers. Around $26.9 \%$ indicated that using both modalities and $19.9 \%$ not using any device.

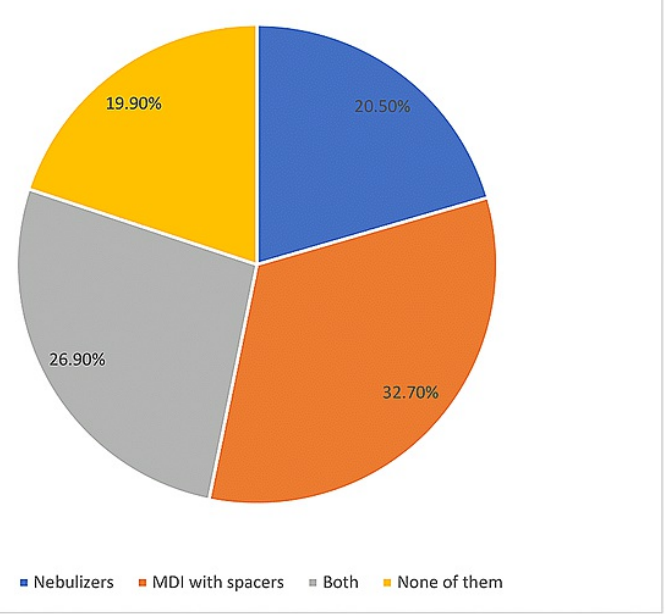

\section{FIGURE 1: Treatment options which are providing to child as a} treatment for bronchial asthma.

MDI: metered-dose inhaler.

Table 2 shows the perception of parents of using MDI or nebulizer. Most of the participants $70.2 \%$ thought that there is a difference in the therapeutic effect between MDI and nebulizers in the treatment of asthma. More than half of them $65.2 \%$ indicated that they had received enough education from healthcare providers for adequate usage of MDI and $43.1 \%$ of them thought that usage of MDI is lifelong. 


\section{Cureus}

\begin{tabular}{|c|c|c|}
\hline & $\begin{array}{l}\text { Yes, } N \\
(\%)\end{array}$ & $\begin{array}{l}\text { No, } N \\
(\%)\end{array}$ \\
\hline $\begin{array}{l}\text { Do you think there is a difference in the therapeutic effect between MDls and nebulizers in the treatment of } \\
\text { bronchial asthma? }\end{array}$ & $\begin{array}{l}717 \\
(70.2)\end{array}$ & $\begin{array}{l}304 \\
(29.8)\end{array}$ \\
\hline $\begin{array}{l}\text { If you are using MDI, did you receive enough education from healthcare provider (nurse, doctor, health } \\
\text { educator) on how to use it? }\end{array}$ & $\begin{array}{l}666 \\
(65.2)\end{array}$ & $\begin{array}{l}355 \\
(34.8)\end{array}$ \\
\hline Do you believe that the asthmatic child who is using MDI will be lifelong dependent on this treatment? & $\begin{array}{l}440 \\
(43.1)\end{array}$ & $581(56.9)$ \\
\hline
\end{tabular}

TABLE 2: Perception of parents of using MDls and nebulizers.

MDIs: metered-dose inhalers.

Figure 2 shows the difference of perception of parents among MDI and nebulizer. The parents thought that nebulizers had a higher therapeutic effect for treatment asthma than MDI ( $45.2 \%$ vs $28.5 \%)$ while $26.2 \%$ did think there is a difference between them. On the other hand, participants indicated that MDI is easier to use (56.4\% vs $22.5 \%$ ). Moreover, around $42.80 \%$ thought that MDI has more side effects and $56.4 \%$ thought that MDI has higher cost.

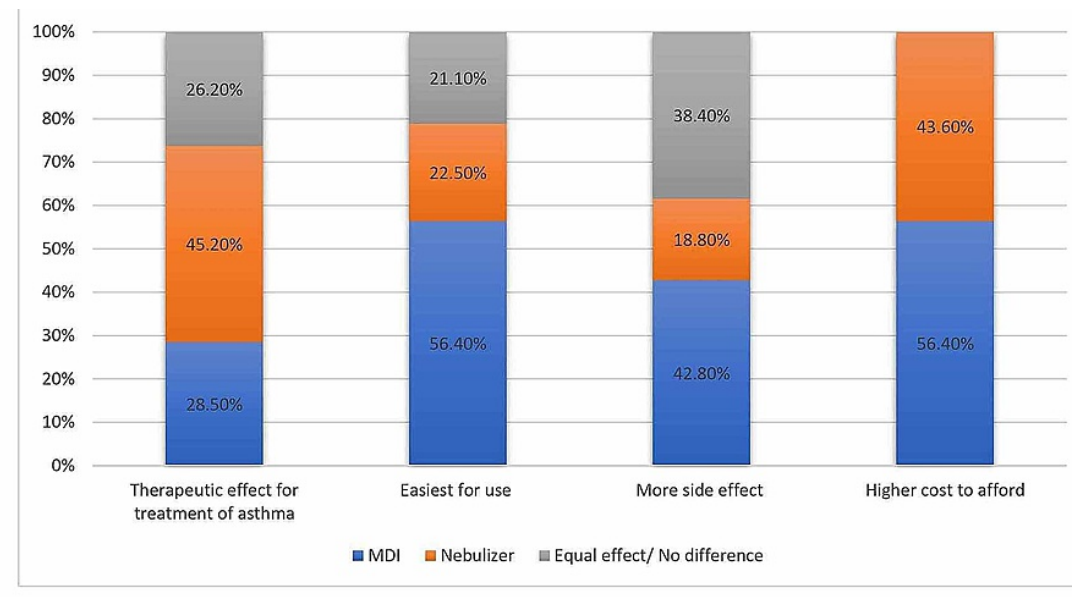

FIGURE 2: Difference of perception of parent between MDIs and nebulizers.

MDIs: metered-dose inhalers.

Table 3 shows considering satisfaction and perception of parents about using MDIs and nebulizers with other factors like sociodemographic data. This study found that the mean score for MDI was $6.01(\mathrm{SD}=2.59)$ which is lower than those with nebulizer where mean was $6.61(\mathrm{SD}=2.63)$. A significant relationship was found between the age of child determines the level of satisfaction for both devices where satisfaction score increase in parents of older children $(\mathrm{P}=0.000)$. However, the age of caregiver didn't affect the satisfaction of parents about using both MDI or nebulizer $(\mathrm{P}=0.621)$. Parents with male children would be significantly more satisfied with using MDI and nebulizer than those with female children $(6.19$ vs $5.69,6.7$ vs $6.43 \mathrm{P}=$ 0.005). Regarding the educational level of parents is another determining factor for satisfaction especially in MDI. This represents that higher education level is associated with higher scores of satisfaction. Another significant relationship found between the education for the usage of MDI and level of satisfaction. Parents who received education for the usage of MDI are more satisfied ( 6.38 vs $5.28, \mathrm{P}=0.000$ ). The perception of parents about safety, usage and effectiveness of two modalities have a significant effect on determining their satisfaction level. Thought of that the device is more effective, less side effect, easier to use and with low cost is associated with higher satisfaction scores. 


\begin{tabular}{|c|c|c|c|c|}
\hline & & $\begin{array}{l}\text { How satisfied are you } \\
\text { with using the MDI, } \\
\text { from } 1 \text { to } 10 ?\end{array}$ & $\begin{array}{l}\text { How satisfied are you } \\
\text { with using the nebulizer, } \\
\text { from } 1 \text { to } 10 ?\end{array}$ & \\
\hline & & $\begin{array}{l}\text { Mean (standard } \\
\text { deviation) }\end{array}$ & $\begin{array}{l}\text { Mean (standard } \\
\text { deviation) }\end{array}$ & $\begin{array}{l}\mathrm{P}- \\
\text { value }\end{array}$ \\
\hline \multirow{2}{*}{ How old is your child } & $<7$ & $5.61(2.72)$ & $6.30(2.68)$ & \multirow{2}{*}{$0.000^{*}$} \\
\hline & $8-14$ & $6.31(2.46)$ & $6.84(2.57)$ & \\
\hline \multirow{2}{*}{ What is your child's gender? } & Male & $6.19(2.57)$ & $6.70(2.57)$ & \multirow{2}{*}{$0.005^{*}$} \\
\hline & Female & $5.69(2.62)$ & $6.43(2.72)$ & \\
\hline \multirow{2}{*}{ How old is the caregiver? } & $19-29$ years & $5.95(2.72)$ & $6.48(2.72)$ & \multirow{2}{*}{0.621} \\
\hline & 30 years and above. & $6.04(2.54)$ & $6.66(2.58)$ & \\
\hline \multirow{3}{*}{ What is your level of education? } & $\begin{array}{l}\text { Primary/intermediate } \\
\text { school level }\end{array}$ & $5.40(2.81)$ & $6.20(2.82)$ & \multirow{3}{*}{$0.000^{\star}$} \\
\hline & High school & $6.00(2.50)$ & $6.69(2.45)$ & \\
\hline & $\begin{array}{l}\text { Bachelor degree and } \\
\text { above }\end{array}$ & $6.21(2.54)$ & $6.70(2.63)$ & \\
\hline \multirow{2}{*}{$\begin{array}{l}\text { Did you receive enough education from } \\
\text { healthcare providers (nurse, doctor, health } \\
\text { educator) on how to use it? }\end{array}$} & Yes & $6.38(2.58)$ & & \multirow{2}{*}{0.000} \\
\hline & No & $5.28(2.47)$ & & \\
\hline \multirow{3}{*}{$\begin{array}{l}\text { Which of the following do you think had more } \\
\text { therapeutic effect for treatment of asthma? }\end{array}$} & MDI & $6.41(2.59)$ & $6.38(2.40)$ & \multirow{3}{*}{$0.001^{*}$} \\
\hline & Nebulizer & $5.67(2.48)$ & $6.79(2.72)$ & \\
\hline & Equal effect & $6.18(2.74)$ & $6.53(2.68)$ & \\
\hline \multirow{3}{*}{$\begin{array}{l}\text { In your opinion, which of the following is easier to } \\
\text { use? }\end{array}$} & MDI & $6.53(2.38)$ & $6.68(2.45)$ & \multirow{3}{*}{$0.000^{*}$} \\
\hline & Nebulizer & $5.04(2.62)$ & $6.53(2.92)$ & \\
\hline & No difference & $5.66(2.78)$ & $6.50(2.75)$ & \\
\hline \multirow{3}{*}{$\begin{array}{l}\text { Which of the following modalities of treatment } \\
\text { have more side effects? }\end{array}$} & MDI & $5.71(2.60)$ & $6.60(2.66)$ & \multirow{3}{*}{$0.001^{*}$} \\
\hline & Nebulizer & $6.23(2.54)$ & $6.19(2.78)$ & \\
\hline & No difference & $6.23(2.60)$ & $6.82(2.49)$ & \\
\hline \multirow{2}{*}{$\begin{array}{l}\text { Which of the following modalities has more cost } \\
\text { to afford? }\end{array}$} & MDI & $5.8(2.60)$ & $6.48(2.66)$ & \multirow{2}{*}{$0.000^{*}$} \\
\hline & Nebulizer & $6.28(2.57)$ & $6.77(2.58)$ & \\
\hline
\end{tabular}

TABLE 3: Satisfaction of parents and their perception about the MDIs and nebulizers.

*Significant at P-value $<=0.05$. MDI: metered-dose inhaler.

Table 4 shows the relationship between demographic factors of parents and children and the parental perception about MDI and nebulizer. In most variables, no significant correlation between these variables and demographic factors found except in the following variables. Age of children, age of care providers and education of parents have a significant effect on the perception of parents about ease of both nebulizer and MDI where parents of older children thought in higher extent that MDI is easier than nebulizer than those with younger children $(\mathrm{P}=0.016)$. The same is found in other factors where higher educated parents thought that MDI is easier than nebulizer $(\mathrm{P}=0.008)$. A significant relationship was found that younger parents had a perception that both tools were easy with no difference $(0.001)$. Moreover, older and high educational levels had more beliefs that MDI didn't relate with lifelong use in children. Gender of children has only effect on the perception of parents about the cost of modalities where parents of male children thought that the two modalities are costly than those with female children ( $67.2 \%$ vs $32.8 \%$ and $60.9 \%$ vs $39.1 \%, P=0.037$ ). 


\begin{tabular}{|c|c|c|c|c|c|c|c|c|c|c|}
\hline & & \multicolumn{2}{|c|}{$\begin{array}{l}\text { How old is } \\
\text { your child }\end{array}$} & \multicolumn{2}{|c|}{ child's gender? } & \multicolumn{2}{|c|}{$\begin{array}{l}\text { How old Is the } \\
\text { caregiver? }\end{array}$} & \multicolumn{3}{|c|}{$\begin{array}{l}\text { What is your level or } \\
\text { education? }\end{array}$} \\
\hline & & $<7$ & 8-14 & Male & Female & $\begin{array}{l}19-29 \\
\text { years }\end{array}$ & $\begin{array}{l}\text { years } \\
\text { and } \\
\text { above }\end{array}$ & Primary & $\begin{array}{l}\text { High } \\
\text { school }\end{array}$ & $\begin{array}{l}\text { Bachelor } \\
\text { degree }\end{array}$ \\
\hline \multirow{3}{*}{$\begin{array}{l}\text { Do you think there is a difference in } \\
\text { the therapeutic effect between MDI } \\
\text { and nebulizers in the treatment of } \\
\text { bronchial asthma? }\end{array}$} & Yes & $42.3 \%$ & $57.7 \%$ & $65.0 \%$ & $35.0 \%$ & $30.3 \%$ & $69.7 \%$ & $16.2 \%$ & $23.2 \%$ & $60.7 \%$ \\
\hline & No & $47.0 \%$ & $53.0 \%$ & $63.2 \%$ & $36.8 \%$ & $33.2 \%$ & $66.8 \%$ & $20.4 \%$ & $25.7 \%$ & $53.9 \%$ \\
\hline & P-value & 0.159 & & 0.575 & & 0.351 & & 0.122 & & \\
\hline \multirow{4}{*}{$\begin{array}{l}\text { Which of the following do you think } \\
\text { had more therapeutic effect for } \\
\text { treatment of asthma? }\end{array}$} & MDI & $46.4 \%$ & $53.6 \%$ & $62.5 \%$ & $37.5 \%$ & $30.9 \%$ & $69.1 \%$ & $17.5 \%$ & $20.3 \%$ & $62.2 \%$ \\
\hline & Nebulizer & $43.9 \%$ & $56.1 \%$ & $66.0 \%$ & $34.0 \%$ & $28.4 \%$ & $71.6 \%$ & $18.4 \%$ & $25.8 \%$ & $55.8 \%$ \\
\hline & $\begin{array}{l}\text { Equal } \\
\text { effect }\end{array}$ & $40.3 \%$ & $59.7 \%$ & $63.8 \%$ & $36.2 \%$ & $36.2 \%$ & $63.8 \%$ & $15.7 \%$ & $24.6 \%$ & $59.7 \%$ \\
\hline & P-value & 0.345 & & 0.605 & & 0.088 & & 0.361 & & \\
\hline \multirow{3}{*}{$\begin{array}{l}\text { If you are using MDI, did you receive } \\
\text { enough education from healthcare } \\
\text { provider (nurse, doctor, health } \\
\text { educator) on how to use it? }\end{array}$} & Yes & $41.6 \%$ & $58.4 \%$ & $65.5 \%$ & $34.5 \%$ & $32.4 \%$ & $67.6 \%$ & $17.0 \%$ & $24.0 \%$ & $59.0 \%$ \\
\hline & No & $47.6 \%$ & $52.4 \%$ & $62.5 \%$ & $37.5 \%$ & $28.7 \%$ & $71.3 \%$ & $18.3 \%$ & $23.7 \%$ & $58.0 \%$ \\
\hline & P-value & 0.065 & & 0.352 & & 0.224 & & 0.856 & & \\
\hline \multirow{4}{*}{$\begin{array}{l}\text { In your opinion, which of the following } \\
\text { is easier to use? }\end{array}$} & MDI & $39.9 \%$ & $60.1 \%$ & $66.0 \%$ & $34.0 \%$ & $28.3 \%$ & $71.7 \%$ & $15.5 \%$ & $21.5 \%$ & $63.0 \%$ \\
\hline & Nebulizer & $50.4 \%$ & $49.6 \%$ & $63.9 \%$ & $36.1 \%$ & $28.3 \%$ & $11.1 \%$ & $18.3 \%$ & $30.4 \%$ & $51.3 \%$ \\
\hline & $\begin{array}{l}\text { No } \\
\text { difference }\end{array}$ & $46.5 \%$ & $53.5 \%$ & $60.9 \%$ & $39.1 \%$ & $41.9 \%$ & $58.1 \%$ & $21.9 \%$ & $23.3 \%$ & $54.9 \%$ \\
\hline & P-value & $0.016^{\star}$ & & 0.412 & & $0.001^{\star}$ & & $0.008^{\star}$ & & \\
\hline \multirow{3}{*}{$\begin{array}{l}\text { Do you believe that the asthmatic } \\
\text { child who is using MDI will be lifelong } \\
\text { dependent on this treatment? }\end{array}$} & Yes & $46.8 \%$ & $53.2 \%$ & $65.2 \%$ & $34.8 \%$ & $35.2 \%$ & $64.8 \%$ & $20.9 \%$ & $23.9 \%$ & $55.2 \%$ \\
\hline & No & $41.3 \%$ & $58.7 \%$ & $63.9 \%$ & $36.1 \%$ & $28.1 \%$ & $71.9 \%$ & $14.8 \%$ & $23.9 \%$ & $61.3 \%$ \\
\hline & P-value & 0.079 & & 0.650 & & $0.014^{\star}$ & & $0.031^{*}$ & & \\
\hline \multirow{4}{*}{$\begin{array}{l}\text { Which of the following modalities of } \\
\text { treatment have more side effects? }\end{array}$} & MDI & $47.4 \%$ & $52.6 \%$ & $63.6 \%$ & $36.4 \%$ & $29.1 \%$ & $70.9 \%$ & $16.9 \%$ & $21.1 \%$ & $62.0 \%$ \\
\hline & Nebulizer & $41 . / \%$ & $58.3 \%$ & $61.1 \%$ & $32.3 \%$ & $33.3 \%$ & $66.1 \%$ & $21.4 \%$ & $23.4 \%$ & $55.2 \%$ \\
\hline & $\begin{array}{l}\text { No } \\
\text { difference }\end{array}$ & $40.6 \%$ & $59.4 \%$ & $63.8 \%$ & $36.2 \%$ & $32.4 \%$ & $67.6 \%$ & $16.1 \%$ & $27.3 \%$ & $56.6 \%$ \\
\hline & P-value & 0.117 & & 0.577 & & 0.449 & & 0.132 & & \\
\hline \multirow{3}{*}{$\begin{array}{l}\text { Which of the following modalities has } \\
\text { more cost to afford? }\end{array}$} & MDI & $45 . \% \%$ & $54.3 \%$ & $6 / .2 \%$ & $32.8 \%$ & $29.0 \%$ & $71.0 \%$ & $16.8 \%$ & $23.1 \%$ & $60.1 \%$ \\
\hline & Nebulizer & $41.1 \%$ & $58.9 \%$ & $60.9 \%$ & $39.1 \%$ & $33.9 \%$ & $66.1 \%$ & $18.2 \%$ & $24.9 \%$ & $56.9 \%$ \\
\hline & P-value & 0.147 & & $0.037^{*}$ & & 0.091 & & 0.586 & & \\
\hline
\end{tabular}

TABLE 4: The relationship between demographic factors and perception of parents.

*Significant at P-value <= 0.05. MDI: metered-dose inhaler.

\section{Discussion}

Asthma is a worldwide disease and considered one of the most common diseases in pediatric populations [1]. The prevalence is increasing rapidly in Saudi Arabia [2]. In enhancing the quality of life of asthmatic children, asthma care has been accomplished, such as offering appropriate medication and preventive steps. Asthma treatment according to guidelines fails frequently [4]. Low adherence to MDI treatment in children with asthma is one of the main reasons why asthma is still associated with significant morbidity, and goals set in the GINA guidelines are frequently not met $[1,8]$. Several factors lead to poor adherence, one of them 
the knowledge and perception of parents toward this condition affect the treatment strategies in children and more important the adherence to prescribed treatments [9]. Therefore, it is very important for regular assessment of this perception and develops methods for improving them. The aim of this study is to assess the parental perception about MDI and Nebulizers differences among the Saudi population.

One of the important findings in this study is that the prevalence of asthma was higher among male than female children with the ratio of about $2: 1$. The previous studies showed that the prevalence of asthma is higher in female than male as the study of Horaib 2018, who had found that asthma prevalence among girls (14.4\%) was higher than boys (12.4\%) [10] and the study of Aliyu 2018, where the gender of the asthma patients were 55 (46.2\%) males and $64(53.8 \%)$ females with male to female ratio of $1: 1.2$ [7]. The high prevalence of male asthmatic children can explain why parents of male children complain from cost of the two modalities than parents of female children. Most of the patients $32.7 \%$ were using MDI with spacers as treatment for their condition while $20.5 \%$ using nebulizer and $26.9 \%$ indicated the use of both modalities. This is different from the reported study of Aliyu where $72.3 \%$ of the respondents would accept MDI if prescribed [7].

The parents thought that there is a difference between MDIs and nebulizers with some preference of one tool over the other in some aspects like nebulizer is more effective, less side effect and cheaper than MDI. On the other hand, they stated that MDI is easier to be used. Around $43.1 \%$ of the parents had myths that since started MDI, would lead to use it for lifelong which is higher than reported in other studies as Aliyu who had found that $51.5 \%$ of parents believed the use of MDI will make asthma protracted [11]. The fining of this study was similar to the results of Bosley et al. who reported their respondents stating that asthma medications were addictive and may be ineffective on prolonged use [11]. These myths were related to some demographic factors as parents of older children and those with higher education thought that MDI is easier to while older and more educated parents had more beliefs that MDI do not relate with lifelong use in children.

A significant relationship was found between the parent perception about the medication and their satisfaction with it and this will affect the adherence of children to medication where thought of that the device is more effective, less side effect, easier to use and with low cost is associated with higher satisfaction scores. Moreover, other factors included a higher level of education would reflect a high score of satisfaction which is similar to Aliyu [7]. Providing instruction and education of parents about how to use MDI, will increase the level of satisfaction and adherence. This is an indication of the importance of providing the parents of asthmatic patients with information about different treatment apparatus and proper information about the disease that will help in increase the rate of adherence providing more control on asthma of their children.

Limitations of this study are people may not answer the questions honestly and precisely, this may affect the data analysis and may result in bias. Also, understanding the questions is very important to limit and minimize errors. Furthermore, uneducated population could also result in bias due to limited knowledge about the questions and the title of the study.

\section{Conclusions}

This study concluded that asthma is more prevalent in females where MDI was the most common treatment used by children. Moreover, most parents had thought that there is a difference between MDI and nebulizer where they thought that nebulizer is more effective, less side effect and cheaper than MDI while they thought that MDIs are easier to be used than nebulizers. Some inadequate perception including that MDI may lead to remain on medication affect the satisfaction of parents. More investigation should be done to study the effect of satisfaction level of parent about one instrument of adherence rate of their children.

\section{Additional Information}

\section{Disclosures}

Human subjects: All authors have confirmed that this study did not involve human participants or tissue. Animal subjects: All authors have confirmed that this study did not involve animal subjects or tissue. Conflicts of interest: In compliance with the ICMJE uniform disclosure form, all authors declare the following: Payment/services info: All authors have declared that no financial support was received from any organization for the submitted work. Financial relationships: All authors have declared that they have no financial relationships at present or within the previous three years with any organizations that might have an interest in the submitted work. Other relationships: All authors have declared that there are no other relationships or activities that could appear to have influenced the submitted work.

\section{References}

1. Zaraket R, Al-Tannir MA, Abdulhak AAB, et al.: Parental perceptions and beliefs about childhood asthma: a cross-sectional study. Croatian Med J. 2011, 52:637-643. 10.3325/cmj.2011.52.637

2. Abu-Shaheen AK, Nofal A, Heena H: Parental perceptions and practices toward childhood asthma . BioMed Res Int. 2016, 2016:6364194. 10.1155/2016/6364194 


\section{Cureus}

3. Alahmadi TS, Banjari MA, Alharbi AS: The prevalence of childhood asthma in Saudi Arabia . Int J Pediatr Adolesc Med. 2019, 6:74-77. 10.1016/j.ijpam.2019.02.004

4. Peterson-Sweeney K, McMullen A, Yoos HL, et al.: Parental perceptions of their child's asthma: management and medication use. J Pediatr Health Care. 2003, 17:118-125. 10.1067/mph.2003.31

5. Conn KM, Halterman JS, Fisher SG, et al.: Parental beliefs about medications and medication adherence among urban children with asthma. Ambulatory Pediatr. 2005, 5:306-310. 10.1367/A05-004R1.1

6. Nambiar G, Rimareva N, Krata L: Parental perceptions about the use of Metered dose inhaler vs Nebulizer in children with acute asthma exacerbation. 2018, Accessed: September 30, 2020: https://pediatrics.aappublications.org/content/142/1_MeetingAbstract/582.

7. Aliyu I, Asani MO, Peter ID, Michael GC: The perception of asthma and views on metered-dose inhaler by caregivers of asthmatic children in Aminu Kano Teaching Hospital, Kano. Med JDY Patil Vidyapeeth. 2018, 11:33-37. 10.4103/MJDRDYPU.MJDRDYPU 16817

8. McQuaid EL, Vasquez J, Canino G, et al.: Beliefs and barriers to medication use in parents of Latino children with asthma. Pediatr Pulmonol. 2009, 44:892-898. 10.1002/ppul.21074

9. Conn KM, Halterman JS, Lynch K, Cabana MD: The impact of parents' medication beliefs on asthma management. Pediatrics. 2007, 120:e521-e526. 10.1542/peds.2006-3023

10. Horaib Y, ALAmri E, Al-anazi W, et al.: The prevalence of asthma and its related risk factors among the children in Riyadh, Saudi Arabia. Egyptian J Hosp Med. 2018, 70:965-973. 10.12816/0044345

11. Bosley CM, Cordenand M, Cochrane GM: Psychosocial factors and asthma . Respir Med. 1996, 90:453-457. 10.1016/s0954-6111(96)90170-5 